\title{
TURKEY: \\ Youth empowerment through governmental initiatives
}

\author{
Murad DUZCU
}

\begin{abstract}
The inception of AK Parti government's initiative to terminate the Kurdish issue in 2009 has paved the way to finding a political solution to one of the most intricate questions of modern Turkey. The political initiatives of the incumbent government not only ended the 40-years-long violence and related terrorism cycle for a short period of time but also promoted a heightened awareness of peace and reconciliation efforts. In regards to the role that they have played during the implementation of recent peace process (2009-2015), Kurdish youth has been frontline proxies of violence instigation. That said, Kurdish youth in Turkey have faced the implications of the conflict since early childhood. Struggling to survive amidst violent occurrences is a part of their daily routine as a result of structural deficiencies and proximate causes of participation in violence. Therefore, this article analyses existing youth peacebuilding initiatives for Kurdish youth in conflict-affected areas of the country. Similarly, it also intended to explore whether these initiatives respond to the roots causes of the conflict.
\end{abstract}

Keywords: Youth radicalization; Peacebuilding interventions; Kurdish Issue; peace processes.

\author{
Murad DUZCU \\ Department of International Relations, \\ Hatay Mustafa Kemal University \\ E-mail: muradduzcu@mku.edu.tr \\ Conflict Studies Quarterly \\ Issue 30, January 2020, pp. 3-30 \\ DOI:10.24193/csq.30.1 \\ Published First Online: 05/01/2020
}


violence cycle in the course of the Solution Process $(2009-2015)^{1}$ but also unveiled an interest in peace and reconciliation efforts after facing repetitive violence for a long period of time. Therefore, with the start of political initiatives in July 2009, Turkey's protracted Kurdish issue entered into a new phase since its inception in the late-1970s. In this phase of the conflict, the political initiatives to end the conflict marked the beginning of an era of efforts to find a peaceful solution to the Kurdish issue in contrast to long-held security-oriented approaches. The process, however, faced internal and external pressures in that the progression unfolded a spiral movement from violence to resilience, which repeated over time as the country went through successive warto-peace transition moments. The governmental initiatives involved careful political considerations of the implementation of the process, legal amendments to resolve conflicting issues, and some public relations campaigns to raise awareness about the Solution Process. Turkey's quest for peace; however, was discontinued when a relapse into violence disrupted the ongoing political process in June-July 2015.

In consideration of these developments, relevant peacebuilding actors were at a crossroads where existing policies, programs to shape youth functioning and young people's potential peacebuilding roles in post-conflict situations meet. A conflict-sensitive agenda for relevant peacebuilding actors in this regard must incorporate all available resources into young people's vast energy to engage them in several peace projects. For that reason, in order to promote and maintain peace and contribute to reconciliation in Turkey, peacebuilding efforts must have an understanding of youth-related issues in conflict-affected areas. Such efforts must consider and invest in the design and development of policy frameworks with broader peacebuilding and reconciliation objectives as a necessary first step.

\section{The youth and violence nexus}

The negative/positive role of young people during and in the aftermath of peace processes has become central to peace and conflict research and the interest on youth roles in such crisis times often stems from the risk factors and contradictions associated with war-to-peace transitions and in post-conflict situations. Hence three major themes have been identified in framing the place of young people in conflict and post-conflict situations: victims, threats (or perpetrators), and peace-makers. These post-conflict roles expand to a debate in peace and conflict research. Specifically, authors such as Graça Machel (1996; 2001) have long paid attention to young people as victims of war and this has led to an advocacy or rights-based approach with regards to young people's

1 The 'Solution Process' is used throughout the article as an umbrella concept to cover all of the initiatives of the Ak Party government in the 2009-2015 period, despite different uses of the specific initiatives and titles attributed to these political efforts such as democratic or Kurdish opening, the peace process, Solution Process etc. 
engagement in post-conflict situations, particularly young persons who are at the early adolescence stage (less than 18 years of age). That is, young people's rights in conflict and post-conflict situations are considered as a human security issue, which needs to be regulated and protected by legal norms and conventions, as in the United Nations (UN) Convention on the Rights of the Child (CRC) of 1989 (see Kemper, 2005).

Following this, recent studies have characterized young people as independent actors in addition to the early portrayal of young persons as victims of war and in its aftermath. However, the term independent actors suggest a positive meaning if young persons are engaged meaningfully, on the one hand, and a negative one if they are frustrated and disillusioned, on the other. In other words, academic studies of youth emphasize that conflict-affected young people may assume roles as agents of peace (peacemakers) or as instigators of violence (perpetrators) (see McEvoy-Levy, 2006).

A relapse into violence can derail peace negotiations and lead to a collapse in conflict settlement efforts (see Darby, 2001). This conception in post-conflict situations necessitates an imperative focus on the roles of young people as they occupy a central position in the relapse into violence. In such post-conflict predicaments, young people are perceived as an important factor in the generation and perpetuation of violence, particularly in opposition to ongoing peace negotiations and against the implementation of peace agreements. The negative role, which young people can play has been the subject of several UN resolutions and is part of its conflict prevention agenda. The UN High-Level Panel on Threats, Challenges, and Change, for instance, referred to how a "surging youth population" faced by a multitude of factors such as unemployment and urbanization can lead to violence or a relapse into conflict (UN, 2004). UN missions to West Africa have similarly reported the link between unresolved socio-economic situations and young people as potential risks to sustainability and security (UN, 2004). The 2001 UN Secretary-General's report on armed conflict stated that young people with limited education and few employment opportunities often provide fertile recruiting ground for parties to a conflict. Their lack of hope for the future can fuel disaffection with society and make them susceptible to the blandishments of those who advocate armed conflict. This problem can be especially acute in countries that have a youth bulge', a population comprised of a large number of youth compared to other age groups ... Addressing the needs and aspirations of adolescence is, therefore, an important aspect of a long-term prevention strategy. In addition, youth can also be an important resource for peace and conflict prevention (UNSC, 2001, p. 124).

Similarly, large youth cohorts in society are also perceived as a security threat in many developing and post-conflict countries, which are often argued by the proponents of the youth-bulge theory (see Hendrixson, 2003; Huntington, 1996; Kaplan, 1996; Urdal, 2004). With its origins in the early works of Heinsohn (2003), Fuller and Pitts (1990) and Goldstone (1991), a 'youth bulge' is defined as "extraordinarily large youth co- 
horts relative to the adult population" (Urdal, 2004, p. 1). In this stream of research, proponents of the theory conceptualize young people as a demographic threat against social well-being and a society's normal functioning. Similarly, a precursor of the debate about young people as a demographic threat in the 1990s was Samuel P. Huntington (1996), who defined $20 \%$ or more young people (between $15-24$ years of age) in the population composition of a country as a sign of vulnerability to violence. In Clash of Civilizations, Huntington (1996) opposed that youth demographics play a crucial role in the instigation of violence, focusing particularly on the Muslim world and on radicalization trends, stating that: "...but the key factor is the demographic factor. Generally speaking, the people who go out and kill other people are males between the ages of 16 and 30. During the 1960s, 70s and 80s there were high birth rates in the Muslim world, and this has given rise to a huge youth bulge" (interview with S. P. Huntington in Steinberger, 2001). Likewise, Robert D. Kaplan described youth cohorts in West Africa as "out of school, unemployed, loose molecules" (1996, p. 16). Finally, Hendrixson (2003) referred to dissatisfied and angry young males in most underdeveloped and developing countries (such as those in Africa, Latin America, Southeast Asia, and the Middle East) as a deviant population and an uncontrolled demographic force in society.

Notwithstanding the alarmist language in the portrayal of young people in the 1990s, recent academic studies in this stream have found that the presence of youth-bulges in (economically and politically) distressed societies correlates with the instigation of violence. Hendrik Urdal (2004) pointed to "intermediary political regimes and negative or stagnant economic growth" in countries such as "Zambia, Kenya, Zimbabwe, Yemen, Niger, Togo, Iran and Jordan" as examples of the causal relationship between a youth-bulge and violence (17). Moreover, Urdal (2004) also suggested a positive link between political change processes (towards democratic governance) and the eruption of violence, particularly in the Arab world where autocratic regimes are able to curb violence despite economic problems and large youth cohorts. A World Bank (2011) report in the aftermath of Arab uprisings in the Middle East and North Africa pointed to a similar notion with anecdotes of popular demands and protests for economic, political and social change as underlying factors in the sudden outbreak and escalation of street violence.

Given that there is a tendency to identify young people as perpetrators of violence or peace spoilers, the contribution of young people to the promotion and maintenance of peace is often disregarded and academic interest in this issue has only developed in the last decade (see McEvoy-Levy, 2013). In contrast to the portrayal of youth as a demographic factor and an agent of violence instigation, recent studies have shown that when they are empowered, young people can contribute to peace and reconciliation efforts. In this context, a stream of research has emerged at the intersection of youth and peacebuilding (see Del Felice \& Wisler, 2007; Kemper, 2005; Kurtenbach, 
2008; McEvoy-Levy, 2001, 2006, 2011a, 2011b; Özerdem \& Podder, 2015; Pruitt, 2008; Schwartz, 2010). Recognizing the positive role that young people can play in peacebuilding, contrary to the previous dispositions, young people refrain or prevent others from involvement in violence and from disturbing the post-conflict order and stability. This fact is evidenced through field research and ethnographic studies on young people's unique experiences of conflict (for instance, see Boyden \& DeBerry, 2004; Collins, 2004; Daiute, Beykont, Higson-Smith, \& Nucci, 2006; 2006; Hart, 2006; Richards, 1996; Shepler, 2005; Sommers, 2006a).

Even so, the presence of a relatively large youth population, as a unique and important demographic dividend in most conflict-affected societies, is detrimental to conflict prevention and transformation, in general, if inclusive policies are not in place. In this regard, young people's mobilization to armed conflict and their recruitment to violent groups as combatants constitute the first layer of academic research on youth and peacebuilding (see Özerdem \& Podder, 2015). The second part is about "resilience, nonviolent coping strategies, care-taking, meaning-making and the social reproduction roles of young people, not just combatants, who are experiencing war" (McEvoy-Levy, 2013 , p. 300). In short, the important role of young people in conflict and post-conflict situations is closely linked to the protection of youth and to young people's representation and empowerment in peacebuilding efforts as part of a comprehensive peacebuilding strategy with the aim of encouraging young people to shape lasting peace and to contribute to justice and reconciliation.

In light of the discussion above on the youth and violence nexus, following sections deal with the historical place of youth in Turkey's society, and particularly the negative role of young people during the recent Solution Process.

\section{Kurdish youth: from 'storm youth' to an uncontrolled cohort}

Historically, the process of politicization and radicalization of Kurdish youth, is premeditated within three periods: "ideological precursors" of organizational structure and political violence in the 1960s-1970s; "human assets" in the irregular fighting within the positions of outlawed groups and terrorist networks since the late-1970s; and "protesters" or "troublemakers" in urban areas since the 2000s and onwards.

The level of political violence in Turkey has increased since the late 1970s at an exponential rate and the Kurdish youth grew into a major human resource for armed groups. In contrast to the rebellions in the Ottoman and early Republican periods, the bearers of the Kurdish politicization in the 1960s-1970s; however, were not the religious or tribal leaders but a new group comprising intellectuals, students, the working class and peasantry. From the 1960-1970s onwards, the role of youth in Kurdish political movement and radicalization of young cohorts is undeniable. This is why, it can be 
argued that young people were at the center of political movements and instigation of violence for decades, yet the features of each cohort were not the same.

The cohort who founded the PKK by using terrorism as a means to ends and launching attacks as a primary method involved an educated group in the main universities of Turkey. This cohort can be considered as the first inner circle of the organization. The occurrences of violence since then have predominantly been instigated by this first cohort. In the meantime, this cohort became narrative-builders in society. Their roles in the making of militarized identities in Turkey's southeast have been a noteworthy component of youth involvement in violence in the later phases. In the second period, cohorts from the 1970s to 2000s have been driven by various methods to join in the organization. The substantial effect of these cohorts was to escalate the number of violent events. As a result, the inhabitants in Turkey's southeast have gradually been socialized in violence by the lived experiences of the conflict environment. As Yavuz (2001) stated, most of the young people who joined the organization in this period came from segments affected by the conflict and then by exclusionary dynamics in society i.e. displacement, neoliberal policies, rapid urbanization.

A third period has been marked by a generation growing up in the conflict environment during the 1990s as the frequency of violence reached a peak. Although it is the fact that agents of socio-political movements were mostly urban and university-educated youth in the 1960s-1970s (see Bozarslan, 2008); the majority of assets of armed groups were peasant youths with no or little education in the 1980s-1990s (see Yavuz, 2001). In spite of the role of an educated cohort during the period of the PKK's appearance, a new generation of teenagers became the potential human assets of the PKK in the 1990s (Bozarslan, 2008). Population displacement and migration from rural to urban areas were the two major reasons for a generation to emerge with inadequate education and low prospects for economic opportunities in the suburbs of major cities, not only in western Turkey but also in the south-eastern provinces. Furthermore, the youth were socialized in violence due to the large number of violent occurrences and through the experiences and memoirs of earlier generations in the 1980s-1990s period. This new cohort has often been called 'storm youth' by Kurdish politicians, composed of angry and frustrated youth groups. This term was invented in the Kurdish body politic to mirror the legacy of conflict on the new generations. In this sense, Kurdish politicians like Şerafettin Elçi, for instance, argued that the current cohort may be the last one to have a sort of dialogue with Turkish counterparts to discuss peace and a possible political solution, contending that new generations have been socialized in violence, and also deprived of manners of dialogue and a collective memory with Turkish counterparts in contrast to previous cohorts.

The mobilization of the cohorts in the 2000s and onwards is, therefore, an exceptionally different case from what was typical in the preceding generations. In contrast to 
the grievances of early cohorts and the translation of young people's frustrations into ideological pretexts for mobilization by conflict entrepreneurs (see Tezcür, 2015; Yavuz, 2001 ) as a result of, for instance, structural inequality or discrimination, past policies and political alienation; proximate factors, such as trigger events (Öcalan's prison conditions and health after his imprisonment in 1999) and external political developments (the Syrian conflict) have started to turn into principal causes of mobilization for political violence in the 2000s.

In sum, a relationship between the instigation of violence and young people was established in the face of youth-led political and anti-social violence in this consecutive periods. This situation has alarmed the public authorities to explore the measures to mitigate conditions that increase young people's proclivity to violence. Various laws and regulations have been passed to confront issues related to youth and children affected by rising violence. The legal documents and proceedings introduced a violence-prone segment of young people to the public as 'stone-throwing children' - (taş atan çocuklar) or 'youth drifted to an offense' - (suça itilen gençler). This language inaugurated a conceptualization of Kurdish youngsters in society that has frequently been used in official vocabulary, legislative acts, juridical cases, and in youth-and-childrenfocused rehabilitation and also social integration programs. Likewise, local branches of the state in Turkey's southeast have concentrated on youth-related issues, initiating programs for the Ministry of Youth and Sports, the General Directorate of Police, local governments, and the Southeast Anatolia Development Project (Güneydoğu Anadolu Projesi) administration. Therefore, it can be argued that the role of young people in the instigation of violence was a totally new situation and became a social problem due to the involvement of a young cohort (1990s-2000s birth) affected by the prolonged conflict environment in Turkey's southeast.

The exclusion of young people from peace processes can yield adverse outcomes. McEvoy-Levy (2001), for instance, argues that alienation of youth from the peace process in South Africa produced negative outcomes as critical roles attached to young people in the fighting stage had been denied during and after the peace initiatives. These developments slowly forced South African youth into criminal activities (ibid). As the political environment in Turkey is often interrupted with the onset of unexpected developments and crises, the presence of a discontented cohort poses similar risks for the continuation of peace efforts. Young people can exploit or endure the execution of pro-solution political activity as substantiated in countless post-conflict settings and peacebuilding practices. In the context of the Kurdish issue, however, young people's role as part of political developments has mostly been negative since 2009. Moreover, youth perceptions of the Solution Process, with reference to their negative role tended to be in conflict with pro-peace politicians' views with regards to the Solution Process. In such a complex political environment, young people have been converted into spoilers of peace in the end, often depicted as an "uncontrolled generation". 


\section{Youth interventions in Turkey's southeast}

This part of the article presents the findings of a fieldwork undertaken in Turkey's southeast in order to evaluate peacebuilding activities for young people and respond to the problems associated with Kurdish youth as discussed in the previous section. Therefore, the following parts of the article provide an evidence-based assessment of key themes that occurred as part of conflict prevention practices in Turkey's southeast, i.e., vocational training opportunities, educational opportunities, empowerment by field visits, youth camps, sports, and festivals, and youth advisors in psychosocial programming, basic skills training.

\subsection{State ownership in peacebuilding for conflict-affected youth}

A fundamental responsibility in the socio-economic integration of youth in the conflictaffected areas of Turkey rests on the implementation of programs by state institutions and through governmental funding. The central government in Ankara, and state-led units and agencies, and their provincial administrative organizations are used to be the major players in youth interventions. The major players in the field of youth-related issues are the Directorate for Youth and Sports (GDYS), Ministry of National Education (MoNE), Social Services and Child Protection Agency (SHÇEK) and the Turkish National Agency for the Youth in Action Program. Also, local governments (municipalities) and the Southeast Anatolia Project Regional Development Agency (GAP) take part in youthrelated activities and projects (UNDP, 2008: 114), especially to deal with the socioeconomic costs of the Kurdish issue. The Ministry of Labor and Social Security, Ministry of Health, Ministry of Justice and Ministry of Internal Affairs also have active youth dimensions within their institutional structures (Göksel, 2007, p. 21). State-led initiatives and funding schemes, such as the SODES (Social Support) program, provide funding for youth-oriented projects. The recipients of such funds are from both governmental and non-governmental sectors: governmental agencies and non-governmental organizations, or directly involved in youth activities.

For Kurdish youth, the most successful programmatic measures aimed at coping with the implications of the conflict are vocational training, educational programs, psychological counseling, youth empowerment efforts and social support programs for basic skills training. State institutions and CSOs often implement these strategies throughout Turkey's southeast in order to prevent youth participation in violence. In the meantime, cross-community interactions in the form of youth empowerment efforts have emerged as part of programmatic responses, which aim to engage Kurdish young people and improve their social integration.

To these ends, one of the major undertakings is the SODES program. Following the inception of PKK activities in Turkey's southeast, the SODES commenced in 2008, with the aim of ensuring the social and economic integration of the most disadvantaged 
sectors of society, including youth, children and women (SODES, 2013). As a statesponsored social support program, SODES is primarily composed of a funding scheme for both public and civil society actors directed towards social inclusion initiatives, and targeting vulnerable sectors through interventions that are aimed at increasing the chances of employability and integrating such vulnerable groups into society via capacity building activities. In this regard, central and local governmental units, such as governorships perform significant functions in implementing the projects as part of the SODES program.

Despite the fact that the program was initiated for beneficiaries such as public institutions and CSOs in the southeastern provinces, the extent and scope of the projects covered by the SODES program incorporated other less-developed provinces of Turkey, including provinces in the eastern region of Turkey (the total number of provinces in the program reached a total of 25 in 2010) (SODES, 2013, p. 3).

Due to the perceived role of young people in conflict settings, the 'youth problem' seemed to attract the attention of state institutions. As a result, several youth centers have been established by the governorships, the Youth and Sports Ministry and the GAP administration. As a youth worker pointed out, recent governmental investments to expand the scope of youth work in the region encouraged the opening of new youth centers, particularly after the establishment of the Youth and Sports Ministry. For instance, the number of Ministry-led youth centers increased from 1 to 4 in the city of Diyarbakır throughout the last decade. This has also increased the number of beneficiaries and the type of activities in such facilities.

\subsection{Vocational training opportunities}

The rise of the unemployment rate, which devastated the economic infrastructure in Turkey's southeast can be seen as one of the costs of the 40-year armed struggle. Acknowledging the economic aspects of the Kurdish issue, therefore, various governments since the 1990s have adopted comprehensive economic development programs, mostly as part of the repeated GAP action plans that involve preventive measures (effective employability policies, vocational training courses, and employment coaching and re-designing vocational schools) in order to assist the economic development of the region. In this sense, it is observed that many actors such as the Ministry of Development, governorships, regional development agencies, the GAP Administration, and İŞKUR (Labor Placement Office) assume key responsibilities when it comes to accomplishing declared broad development objectives. On the economic inclusion of Kurdish youth, for instance, SODES-funded projects appear as one of the most efficient youth initiatives. To exemplify the extent of the program, under the employment action of the SODES funding scheme, 6792 participants have been assigned a job between the years 2008 and 2011 (excluding employment at public institutions) (SODES, 2013, p. 45). During 
the field research in Turkey, participants often referred to the role of SODES-funded programs in the economic empowerment interventions. Therefore, several interviews with key experts in the head offices and training centers of state and CSOs have been conducted in order to shed light on the efficacy of their programs. To demonstrate the role of several actors in economic empowerment activities, it is observed that CSOs frequently consulted with the ISSUR and local employers at the design and implementation stages of the activities to meet the requirements and pressing needs of the local employers. There is also a division of responsibilities when it comes to engaging different categories of young people. Particularly, regarding the criminalized youth and children, state agencies for the youth services (SHÇEK), and Emniyet Genel Müdürlüğü (Police Department) undertake fundamental responsibilities. In a project entitled 'Umut YlldizI', for instance, the contribution of the police force in Diyarbakır to the employment of youngsters, who have been convicted of drug use, could be described as exemplifying the active participation of the Police Department in the social integration of young people in the region.

In such activities, the aim is often to train young people in activities to meet the local industry's intermediary positions such as operating computer-based machines, and self-employment jobs such as tailoring, sales assistantship, barbering, and computer programming. Certain matters of concern appeared that are often raised in the interviews with key staff regarding the activities provided for vocational training courses. For instance, it was observed that the employment success of participants after completing vocational training courses appeared to be linked to the type of activities provided and the proficiency levels of the host institutions, as well as the local employment needs and capacities. As one of the interviewees argued, it is very likely for participants to find a job after graduation if they acquired the necessary skills required to satisfy the demands of the local industry. In the meantime, he stated that job prospects are directly connected to the job supply and economic activities in the localities. This latter situation is particularly crucial for Turkey's southeast as the economic opportunities have traditionally been lower, and the economic and commercial activities further affected by violent clashes and sabotages since the inception of PKK activities in the region. Another interviewee alluded to this notion and argued that host institutions' relations with the local industry and their willingness and capacity to supervise participants' job search are also as important as the domestic economic conditions in a specific location. For instance, he mentioned that they not only try to predict the local industrial trends and needs before starting a vocational training course, but also directly get involved in the arrangements for a job interview and placement with potential employers.

A crucial aspect of current youth activities is that local police forces play a positive role when it comes to assisting the CSOs in selecting participants among marginalized and disadvantaged groups. This includes particularly young people who have been involved in violent and criminal activities and ex-PKK members who have benefited from the 
repentance law. According to the interviewees, CSOs frequently collaborate with police forces, both to involve particular types of participants, as well as to secure the spaces from various security breaches due to participant profiles. Such special arrangements are in place for a limited number of activities as most of the economic empowerment activities administered by public and civil society actors rely on open calls for admission processes, reaching all sectors of society.

The physical environment in the vocational training courses could also be perceived as a factor that contributes to the skills acquisition process positively or negatively. With that said, the places visited in this study demonstrated that some spaces were inadequate regarding the number and skills of the staff, and the availability of material resources. There were also institutions equipped with high-quality machinery identical to the ones used in industrial facilities. Regarding the use of such spaces by the participants, however, one of the interviewees mentioned that they frequently face instances of misuse and pocketing the amenities in their centers. She argued that the instructional materials, especially drillers and supplies that could be used for an offence and drug abuse, have frequently been stolen when they commence the courses for the youth who have once been sentenced and released for certain crimes and anti-social violence. She further argued that a certain number of CSOs and public institutions, therefore, have intentionally been prevented from initiating activities for such youth groups.

Another issue that emerged during the interviews has been the disparity between the expectations of the participants after completing the training, and the appropriate skills that they have acquired throughout the courses. For instance, one interviewee mentioned that those who gain basic computer skills expect to find jobs as if they were computer engineers. This situation can clearly be seen as a critical dimension of youth frustrations whereby young people who have been alienated from education due to the existence of political conflict and the violent environment, expect to find valued economic positions in society. Most of the participants also argue that intermediary jobs are often discriminated against by the general public, and the vocational courses that are usually aimed at training youth for such posts are undervalued, and sometimes could be counter-productive. It could also be argued that similar problems exist among the educated youth cohorts, particularly after graduation. As higher unemployment or under-employment is one of the most pressing issues of conflict and post-conflict situations, these aspects frequently become the lively topics of several peacebuilding interventions.

\subsection{Educational opportunities and young people's social integration}

State institutions and CSOs, provide educational opportunities for youth and support educational inclusion activities by launching additional educational courses aimed at preparing them to excel within the school system. In this regard, such opportunities 
often target high school students, who are pursuing success in the nationwide university entrance exams in order to reserve a place in higher educational institutions. Enhancing educational opportunities for disadvantaged groups, particularly for young people who have traditionally been the most vulnerable sectors of society, such educational courses contribute to the conflict prevention agenda in Turkey's southeastern provinces. As one of the interviewees urged, involving young people in the educational system is a major challenge in many neighborhoods for a variety of reasons. According to him, most parents are not interested in their children's educational advancement, which is partly due to the financial problems, resulting in many deprived families being unable to afford educational expenditures. Considering the prevalence of big families, which are roughly composed of 4-5 school-age children, their educational expenses put a heavy fiscal burden on already very limited budgets. Financial circumstances also compel some families to consider youth and children as part of a workforce required for the family to earn and contribute to the household income. This latter situation is the case in rural areas of Turkey's southeast, where children and youth participate in the family businesses such as farming and livestock production. In the urban centers, however, they often get involved in the informal economy and sometimes forced to participate in illegal business activities.

It can be argued that recent educational investments, as part of the democratization efforts in the predominantly Kurdish populated areas in Turkey, are motivated by a motivation to accelerate the social transformation in order to promote a peaceful environment. There are certain structural issues that thwart the efforts made to generate the intended results. For instance, as one of the civil society leaders argued, the region has long been suffering from insufficient educational infrastructure, i.e. the shortage of qualified manpower and educational facilities. He argued that teachers and staff who are appointed by the central government and who are also from the western regions of Turkey, often pursue the occasion to leave their posts in the southeastern provinces of Turkey. This situation hinders the stability and quality that is required for success in the educational system, which altogether causes frustrations among the local population. It was also mentioned that the language barrier could be a reason for the alienation of youth from education. Since most students learn Turkish language mostly after their enrolment in first grade, their inclusion into the educational system poses a challenge that affects the cognitive learning abilities of pupils. Also language barrier impacts the teacher-student relationship. For instance, one of the interviewees mentioned how their inability to speak Turkish is criticized by the teachers. Moreover, a structural problem such as the prevalence of the use of violence in school influences young people's schooling rates and success. Interestingly, another participant, working as a teacher in one of the schools in Diyarbakır, complained of the fact that teachers could also be exposed to violence coming from mature students and their families. 


\subsection{Empowering youth with field visits, youth camps, and sports}

Young people's engagement through recreational activities is the most widespread tool used by both public and civil society actors in youth interventions. The methods used in young people's social inclusion should move beyond basic needs such as education or employment. That being said, such initiatives need to be comprised of elements that nourish the relational aspect of socialization, generating a socially inclusive environment, in which individuals find the opportunity to build constructive relations with others. In this sense, addressing the issue of resentment and antipathy towards other members of the in-and-out-groups is one of the building blocks of youth empowerment. Youth empowerment efforts were also mentioned by most of the key experts like the chief mode of activities that exists in the region. In this sense, engaging young people in recreational activities, such as inter-regional field visits, youth camps and festivals, youth actors appear to fulfil peacebuilding roles in order to help young people overcome the difficulties that arise as a result of instances of violence occurring in or near their neighborhoods, as it limits their social development and interactions in the larger society.

It has been observed that cross-community field visits function efficiently with regard to shaping young people's perceptions of the 'self', and 'others' by visiting different parts of the country. It is expected to help reduce long-established stereotypes and prejudices that can be observed in the narratives of violent groups and networks. Participatory dialogue can be considered as a constructive approach in the activities of public and civil society actors, which often involve aims such as changing the perceptions of Kurdish youth by enabling them to visit other geographical regions of Turkey, as well as by helping them to form new relationships with their counterparts in the provinces they visited. These types of activities generate negative results as well, since young people are more likely to compare the prosperity in other regions of the country with their own war-torn, lacking environments. An interviewee from the public sector, for instance, highlighted this fact and said that it could reserve the benefits expected from such activities if the aims are not well explained to the young people. He further suggested that the pre-visit informative training and practices overcome the difficulties that might arise at the end of the youth interventions:

While our objective is fostering a sense of belonging among young people to the country, young people who visit the places like Antalya or İstanbul, and then return to their homes could ask: 'why are they living in very pleasant cities, and we are living a life of misery?' We should not let them say this. Then, it would not mean anything even if we wanted to do something good. It would turn into a pointless experience for both sides. This is why, we, first, prepare its background before initiating a project. We do not directly ask youngsters to come with us to the excursions, but we clarify them objectives in the courses in advance for 
about 7-8 months to prepare them for further similar interactions, like organizing sports activities, arranging visits and picnics within the city boundaries.

It is clear that building trust and eliminating prejudice among youth in both the western and southeastern provinces must be a vital component of existing and future peacebuilding activities in Turkey. Similar social impacts of youth projects can be observed in the experiences of Turkish young people who have been mobilized for face-to-face interactions with their counterparts in the southeastern provinces. For instance, one of the interviewees working as a project officer in a youth organization in Istanbul referred to their youth project as a 'Peace Bridge', and commented on the experiences of Turkish young people in the region:

It is quite crucial to listen to people's complaints in its local contexts. And it is not significant to do this in Istanbul but to achieve it in Hakkari. That's a significant activity when young people arrive there and communicate with locals, and thus begin to break their prejudices. For instance, recently one of our volunteers told us that he had lots of prejudices when they went to the city of Van for a school renovation project. He further said, however, "once I had conversations with the people in Van, then I found the chance to realize the extent of shared values and the abundance of common things to talk about". I think this is crucial because if there would be a transformation, and we enter into peace environment, these would happen once the people get to know about each other. It is not wise to do this based on information on the TVs. You should travel there and talk to the people. We also organize the same activities to the west (Turkey).

Young people's participation in sports activities occupies a significant part of youth centers' activities. The increasing interest in sports activities as a means of empowering young people is one of the strongest ways when it comes to improving social integration of youth in conflict and post-conflict situations. The importance that is given to the relationship between young people and sports as a means of social inclusion can be traced back to the national youth policy in Turkey. As one of the social worker interviewees argued, the state bureaucracy in Turkey has long been equating young people and sports in order to redirect young people's vast energy into an active path, in a way to reveal a point of escape for young people who are affected the most by the implications of the prolonged conflict environment. In fact, the national higher authority for youth affairs in Turkey's capital is called the Youth and Sports Ministry, reflecting the significance of sports and its relationship with youth empowerment. This is why, in most of the youth centers, sports trainers work alongside other instructors and youth workers to engage young people who might be interested and have the capability to do extremely well in one of the sports branches provided in these centers. Among others, martial arts, boxing, and other individual sports activities are usually the most popular branches among the participants. Regarding the relevance of sports activities, most of 
the interviewees noted the effectiveness of such activities in preventing young people's participation in violence. That is, sports activities not only enable young people to gain self-confidence but also, excellence in a sports activity leads to economic benefits, social status and prestige. One of the interviewees, a sports trainer in a youth center, for instance, mentioned that:

Sports activities occupy a large segment of our operations. To give an example, recently, we learned that one of our participants entered the physical education department in Y province. If I may say so, these young people were amongst those who were throwing stones at the police forces, without a future or hope. After we started to work with them for 5-6 years, he became a national sportsman, and in the meantime, now started a job as a physical education teacher.

The success story of young people from the southeastern provinces who have been competing in national sports events often capture the headlines in the national news, very similar to the example referred to in this above excerpt. As another sports trainer interviewee argued, the sports initiatives are uniquely compatible with the existing socio-economic situation in the region, first, because of the widespread interest in sports activities as a means of providing economic incentives. Second, he stated that sports education in higher institutions requires a physical capability, in contrast to other educational branches, which attract more people from the region. Acknowledging the inadequate educational infrastructure, and conditions that prevent young people from attaining a better educational background, excellence in various branches of sports and its education, apparently, provides a crucial incentive for the youth. In return, the likelihood of their involvement in violence is being reduced significantly.

\subsection{The role of youth advisors in psychosocial programming}

One of the most pressing issues regarding youth experiences of political conflicts emerges in the areas of past and on-going traumas, which inhibits young people's meaningful participation in society. It is observed that SHÇEK is a competent actor, especially when it comes to addressing young people's social and psychological needs. Similarly, youth centers function as hubs for young people, enabling them to overcome the implications of their conflict experiences. In recent years, violent incidents instigated by Kurdish youth, along with the on-going peace process in Turkey have heightened the need for the participation of young people with positive roles within society, more than any other period since the 1980s. However, Kurdish youth have frequently faced the implications of the surrounding fragile environment, in which several forms of violence have been nurtured by the cyclical armed clashes in the region, and as a result of traditionally constructed structures. For instance, escaping from domestic violence or violence in the streets or school, it was observed that youth centers often emerge as spaces, which shelter young people from the costs of the nearby fragile environment. As they experi- 
ence problems with their parents and peers, youth centers provide the means to cater to their psychosocial needs. A youth worker in one of the youth centers, which is located in Diyarbakır's midtown area, stated that most of the centers in their city had become alternative spaces for them, as they have been isolated/escaped from violence-prone environments. He stated that young people have frequently been exposed to several forms of violence in their neighborhoods, schools, and within families. He further said that in youth initiatives such as study halls, rehabilitation services, and spaces to engage youth via youth advisors, young people are joining an entirely different atmosphere in which there is no alcohol, drugs or violence.

These views were echoed by another informant who was formerly a teacher in Diyarbakır before becoming a youth worker at one of the centers established by the Youth and Sports Ministry. He highlighted the role of advisors and instructors in the centers, helping young people to cope with the dilemmas of their daily interactions. Young people's interactions with advisors appear as part of their regular everyday work. Young people's frustrated upbringings often surface when they are emotionally upset with their parents and siblings, or distressed because of being exposed to physical violence, which befits them to the youth services provided by Diyarbakır's youth centers. As one of the youth workers highlighted: "we are receiving letters from participants stating that, today, I was flattered by the instructor, and they never get angry with us". He further said, "it is often regarded as a naïve thing for ordinary people to encounter this (being flattered), but they are apparently deprived of such interactions in their near surroundings". The fact that they are deprived of fundamental emotional needs, and encountering the absence of constructive interactions with peers and parents, these youth centers provide the opportunity for youth to establish meaningful and lasting connections with participants in the centers and youth advisors. Besides the emotional attachment between the youth and advisors, the latter's social profile often set a good example in young people's life choices. For instance, a youth worker, to illustrate both the attachment and role-model functions of advisors, noted that:

Teacher X has had a student here. His father passed away a year ago. He was not going home. He was spending more time with X than his family. Apparently, he had problems at home and found the compassion and natural affection here. Young people are joining in here, either for material gains or attach themselves with emotional ties, as in this one. Those who are linked to only material benefits often split away and we cannot keep in touch with them further in future. However, once emotional attachments are established the communications usually continue afterwards. 


\subsection{Capacity building training}

Capacity building training is another key component of programmatic responses to address youth needs in conflict and post-conflict settings. As aforementioned, the scope and extent of program areas often overlap in the course of the implementation stage, which can be seen in the core competencies training activities as well. Emphasis is mostly given to human rights awareness initiatives, as it is the most observed entry point in the activities of civil society. A role can be assigned to the EU-sponsored activities aimed at the dissemination of European values and non-formal education as part of the EU's Mediterranean partnership program. Since the most pressing issue of the prolonged conflict environment in the region, human rights activities feature as one of the most significant peacebuilding intervention. In this regard, increasing young people's awareness of universal human rights values, building the necessary capacities to monitor human rights abuses and advocacy activities appear to occupy a major role in civil society initiatives. To this end, a social activist working in one of the most recognized human rights associations in Şanlıurfa commented that:

Our work as a civil society organization is aimed at spreading the peace and prosperity ideals for young people through creating a youth consciousness by providing educational activities...This educational work is particularly on social issues; and experts, intellectuals, academicians, legal practitioners are usually invited to deliver seminars to contribute to the development of social consciousness in the society... We have a clear distance to triggering crime and violence, and supporting armed activities. Therefore, we are promoting democratic rights of all, and working towards an environment in which people freely exercise such rights. Our thinking, thus, by adhering to the ideals of human rights, aims at enhancing such practices to all segments of the society.

As she explains, human rights awareness initiatives frequently dominate the activity agenda of civil society in the region, which was also discerned in the fieldwork visits to the other provinces in the area. In these campaigns and educational activities, young people are often 'objects' of the civil society human rights programs. For instance, the role of youth in these activities is limited to showing up for press releases or demonstrations and attending the public lectures of high profile individuals. Therefore, the perceived functions of civil society, in this sense, do not surpass the utility of a human rights course offered in formal educational settings. In contrast, unconventional methods, such as initiatives involving various features of informal and peer education, and vesting in youth 'agency' in the first place by including them in the knowledge and experience give-and-take processes can be seen as one of the necessary means of observing the actual impact and expected personal changes in relation to youth perceptions of the 'self' and 'others'. It is found that some civil society initiatives address these objectives. For instance, a foundation, which has been established as a network of youth 
volunteers, and headquartered in Istanbul, operating through subgroups comprised of mostly university students and organized in almost all of the provinces of Turkey can be seen as one of the most effective practices. To encourage young people to take part as a 'subject' in the awareness campaigns and activities of complicated human rights and social issues, a youth activist, for instance, described young people's participation as both participants and trainers in their interventions:

What we observe is that they acquire the basic human rights awareness and advocacy skills during 4 years of participation period (this refers to the university education time as most of the participants are initially college students) in the foundation's activities. If they become trainers the impact increases exponentially, so the transformation of their agency. Accordingly, they have the opportunities to visit different locations and receive some skills from the 'training of trainers' activities. If they only participate in the organizational activities, they are still subject to a sort of personal transformation and acquire some skills in the face of mutual interactions. Our efforts to install a "volunteer's consciousness" into youth could become a feasible objective as the participants are now able to internalize an approach to intellectually process the cohabitation of cultural differences at the end of the activities.

Similarly, he also pointed out the role of peer education as an effective mechanism for knowledge and experience exchange:

Young people who participate in our activities frequently refer to the peer education as one of the best practices in our foundation's activity pool. In such activities young people find the opportunity to deliver the training to their counterparts. This training includes human rights education, social rights, and reproduction health. Therefore young people as mentors communicate their experiences with other youths... The significance of this type of activities highlights the fact that young people usually listen to their elders, yet the actual learning process occurs among them. It is, in fact, true that we often comprehend the topics better once we are talking to our peers because your role models are indeed the ones by your side. That old typical notion of taking someone as the role model in my life does not exist anymore.

\section{Socio-political barriers to conflict prevention in Turkey's southeast}

There are a number of conflict prevention interventions examined, which are quite successful in responding to the socio-economic implications of the prolonged conflict in Turkey's southeast. Social support projects as part of the SODES program, for instance, can be seen as one of the broadest funding schemes in comparison to conflict response programs elsewhere. Governmental partnership with the CSOs, in this sense, stimulates promising social integration outcomes. Building the educational infrastructure of 
deprived areas of Turkey's southeast after the inauguration of democratization efforts can be seen as investments, which address the ignored educational consequences of the conflict. Recent improvements in educational infrastructure go beyond the governmental and private investments in comparison to the entire Republican era since the 1920s.

However, jobs for marginalized young cohorts, participation in sports activities, or a university degree might not be a solution or alternative for some young people's social inclusion or non-involvement in violence. This is partly an outcome of ethnic and political conflicts, which are often a function of the root causes that are further than acute economic or social problems. Therefore, it can be argued that peacebuilding as a strategy to disclose and help to overcome the root causes of conflicts, entails peacebuilders not only to reserve resources in reviving the socio-economic structures but also to change the relationships and transform the agency of conflict-affected individuals. This strategy can be one of the ways to solve political conflicts where individuals are ideologically indoctrinated and mobilized by ethnic, irredentist or nationalist ideas.

\subsection{Ideological challenges in peacebuilding work}

Despite economic and social problems associated with the conflict in Turkey's southeast that has lasted for over 30 years, qualitative data obtained from the field research accumulated diverse views and conclusions regarding the role of factors in young people's social inclusion. Some key experts and state employees have paid more attention to the socio-economic inequalities and inadequate education opportunities as the major indicators of young people's participation in violence. These informants have stated that youth empowerment through socio-economic measures are an efficient tool when it comes to integrating a conflict-affected population into society. They reiterated the fact that socio-economic issues have long been known as the inherent characteristics of Turkey's southeastern provinces that need to be addressed as part of peacebuilding initiatives and to find a permanent political solution to the Kurdish issue. From their perspective, a causal relationship exists between socio-economic backwardness and the Kurdish issue. Therefore, drawing attention to the impact of socio-economic backwardness on the inception and escalation of the conflict in Turkey is also a way of dealing with youth needs and concerns. This relationship is evident in the profile of the recruits of extremist and terrorist armed groups, indicating that most of the members of such groups are unemployed and uneducated young people at the beginning of individual recruitment processes. Providing socio-economic opportunities for them, the role of state-affiliated institutions is expected to reduce the prospects of youth involvement in violence as long as they are empowered with skills and tools to become a valued member of society, and therefore helping to break the vicious cycle of recruiting new members to violent armed groups.

Socio-economic conditions, however, seem to indicate less significance compared to or without considering other significant root causes or factors of the conflict. In particular, 
ethnic identity salience, acquisition of cultural rights, such as education in the native language, appears as the most significant conflicting issues. Despite the fact that the majority of recruits are unemployed or uneducated, university graduates and economically stable persons also participate in violence. This is an attribute of recruitment processes in ideological and ethnic groups. To this end, the prevailing narrative used by violent groups about politicization has been the role of traditional socio-economic structures in exploitation of rural population.

Therefore, the socio-economic integration of young people is interpreted by violent groups as an influencing behavior of others for their own purposes, which causes young people to leave their fanatical ideological views. Socio-economic opportunities provided by the state institutions, for instance, are being interpreted as a part of the political agenda to eliminate the influence of such ideological pretexts in young people's decision to participate in violence. The state's socio-economic projects in these provinces are, then, is disputed. These facts are evidenced in the offensive actions of the PKK that regularly aim to disrupt the economic infrastructure and interrupt the educational system. While young people are the most important actors in these types of actions, such activities also show the logic that how socio-economic issues are being construed by violent groups.

The categorical affinity between the views and actions of young people and the narratives of violent groups highlights the role of ideological indoctrination and politicization of youth grievances to shape the 'agency' and 'positions' of youth in the society, which frequently limits the efficacy of socio-economic integration interventions. In this sense, interventions that improve socio-economic opportunities are not valued to impede youth participation in violence. Thus disregarding ideological and ethnic aspects, peacebuilding interventions are inefficient tools in conflict prevention. Likewise, interventions that aim to improve socio-economic opportunities are sometimes directed at the wrong audiences, as these activities usually target young people who are not ideologically inclined to the ideology as claimed by the violent groups. Besides, even when vulnerable youth clusters are engaged in peacebuilding initiatives, they frequently face ideological indoctrination at some point in their lives, especially during higher education years.

\subsection{The selectivity of youth practices and impenetrable youth spaces}

The presence of several youth categories in Turkey's southeast; peacebuilders usually seek different socialization means for each youth group. In most of the cases, actors, spaces and perspectives linked to the youth activities are highly selective about participants and the scope and extent of activities supplied for them. In other words, it may be impossible to set up a forum for young people from different backgrounds for a training course, unless members of each sub-group are fully satisfied with the aims and profiles of peacebuilding actors. These assumptions have partly been derived from 
the field observations and informed by the interviews with key experts by analyzing responses to issues seeking to describe beneficiaries from youth activities, and enrolments into such programs. For instance, in one of the interviews, it has been explicitly mentioned that certain categories of youth have been excluded from the activities, such as criminalized youth. Moreover, some young people purposely select activities in line with personal preferences of ideology, family or religious affiliation. Therefore, it can be argued that young people in Turkey's southeast are a highly fragmented social group in observation of the characteristics, and spaces they do attend regularly. However, youth categories are not composed of mutually exclusive groups of young people since one individual may participate in more than one activity or group, and/or switch into another category at a particular moment of their lives.

\subsection{The actor/implementation problem}

In contrast to the conflict situations in different places, international programs for young people are mostly superseded by national schemes in Turkey. A possible explanation for this might be that unlike instances of conflicts elsewhere, the Kurdish issue has been a conflict that emerged between the state, and an outlawed group, which has used terrorism as the modus operandi to realize its political objectives. Therefore, the Kurdish issue has been viewed through a security lens, and countering violence has become a primary goal, that constrained discussions regarding the Kurdish issue into the national boundaries and has attracted national intellectual and material resources. Also, in most conflict situations, state authority is weakened by the repercussions of the armed conflict; therefore, the resources for post-conflict reconstruction activities have already been lacking. International funds aim to revive such 'failed states', instead of allocating resources to states with already functioning administrative apparatuses.

With regards to state-led youth initiatives, however, they are externally planned and rarely reflect local contexts and priorities. Personal biases are often on the grounds of family disapproval to participate in such activities. Economic and political measures that are formed to assist post-conflict reconstruction strategies are typically confined to externally driven goals, such as promoting liberal economic systems and developing more democratic societies. However, this approach consistently neglects local perspectives and overlooks inconceivable issues, such as culture and identity, inherent conflicting relationships and conflict traumas that are considered as the root causes of conflict. Therefore, addressing sensitive issues for one of the most vulnerable segments of the conflict societies, youth policies and programs should suggest solutions by reflecting on several dimensions of the conflicts and produce multi-faceted approaches in a way to think about young people's needs and concerns. This includes changes/transformations in established structures, antagonistic relationships and biased perceptions, which consistently reproduce conflict drivers. These approaches, in return, require an in-depth investigation of issues surrounding young people but most importantly, necessitate 
familiarity with the local circumstances and indigenous methods for peacebuilding activities that are often embedded within the existing social structures and relationships.

\subsection{Youth profiles in selected peacebuilding work}

The peacebuilding initiatives partially address the needs and concerns of conflict-affected young Kurds and fail to reach the most serious categories of Kurdish youth. In contrast to the conflict experiences away, economic and educational opportunities may not provide the necessary tools to socially integrate conflict-affected youth, although these factors, as evidenced in many other conflict settings, are also among the major issues of concern in Turkey's southeast. Therefore, a comprehensive peacebuilding strategy, entailing context-specific measures that recognize young people's perspectives of the conflict, and similarly incorporating local concerns into existing youth activities, necessitates reflecting on peacebuilding initiatives in different conflict settings and learning from the lessons drawn from different youth-oriented peacebuilding initiatives.

Certain disadvantages in youth initiatives often limit the capacity and impact of youthoriented activities, despite good practices and success stories. State-led efforts were initially intended to engage several categories of young people in the operational precincts. As one of the youth workers put it, the 'selection of participants are not on the grounds of political preferences', and they accept 'young people as long as the capacity of centers allows receiving further participants'. However, amongst the youth who participated in two different interviews conducted in the Sanlıurfa and Diyarbakır provinces, two divergent discourses emerged. Firstly, a considerable number of participants mentioned that family disapproval against these types of activities on the grounds of mixed-gender activities and other religious factors inhibit their participation in such youth activities. Secondly, some participants were biased against state-led activities, due to their ideological/political backgrounds. Together these observations provided insights into the personal and familial preferences of the local people regarding youth participation in particular types of activities and gave hints about the sustainability of peacebuilding activities in Turkey's southeastern provinces. Considering the predominant traditional and religious aspects of local culture, and discriminatory personal preferences, such evidence represents one of the crucial factors that need further reflection when designing and implementing peacebuilding activities for conflict-affected youth.

While the peacebuilding interventions initiated by several actors have targeted conflictaffected youth, because of their interest in the activities in line with proximate ideologi$\mathrm{cal} /$ religious associations, they split youth into various ideological/religious groupings. In these groups, peers or mentors deliberately spread ideas to help form young people's minds along with the youth-oriented activities or programs. The diversity of actors and programs in peacebuilding work is a sign of effort by adopting strategies addressing very specific youth needs and challenges, as long as they are in line with the peace pro- 
cess in Turkey. However, considering the sharp split in ideological/religious lines, the competitive edge for recruiting youth into the affiliated youth groups, and incompatible perceptions of each other inhibits the peacebuilding strategies towards building trust and reconciliation in the region, and in particular among conflict-affected sectors of the society. A plan to establish peace structures that lay a new framework for cross-group visits to alleviate collaboration, and to relieve the tensions among these groups are an effective means of overcoming the issues of multiple actors in peacebuilding activities.

\section{Lessons learned and recommendations}

Political and administrative institutions in Turkey's southeast need to take into consideration of the role of institutional deficiencies regarding a nationwide youth policy as the first dimension of post-conflict reconstruction efforts in addressing the concerns of young people to enable them to practice peacebuilding roles in a conflict-free society. Second, it is frequently argued that the undesirable implications of the conflict have long been felt in big cities after the forced migration of the conflict-affected Kurds to urban centers in Turkey's southeastern and western provinces. In this context encounters between Turkish and Kurdish residents and between the rural and urban populations within the mostly Kurdish populated areas have exposed the risks for youth participation in violence. Lastly, responding to the social consequences of the Kurdish conflict requires to take action about the identity related issues as part of the root causes of the conflict. This fact requires conflict transformation skills at the individual level that involves changes in attitudes and behaviors of young people. In particular, a significant role in this respect rests on political elites as the political positions and ethnic goals, in particular, are some of the primary incentives for youth mobilization that shapes the nature of personal development processes for young people in wider society.

To sum up, the following lessons can be drawn from the field research in Turkey's southeast:

- Existing youth programs should employ a comprehensive assessment of the characteristics of the youth population in Turkey's southeast. This evaluation must reflect the contextual factors, such as the religiosity and traditional features of the Kurdish society.

- Widespread regional (economic and social) development programs often fail to respond to the personal aspects of youth participation in violence. This assessment usually prioritizes providing educational and economic opportunities as a ubiquitous programmatic response for existing youth challenges. Such a structural approach, however, often ignores the role of 'agency' in young people's decisions to participate in violence.

- Due to the dominance of a 'structural' attitude in addressing youth challenges in society, existing youth programs often involve young people in peacebuilding to an 
extent and a level. In this regard, young people's personal development processes, particularly following the secondary or high school stages, are usually left to the influences of 'other' social and political actors. This 'gap' leads to coaching young people starting from very early ages in line with the agendas of these political/social actors.

- Community-level mechanisms in order to prevent youth participation in violence can be an efficient tool based on the prevailing features of the Kurdish society. Due to the negative reputation of social actors such as the traditional religious or tribal groups, particularly in the rural areas, these actors fail to act as suitable agents for youth empowerment in peacebuilding. The fundamental changes in Kurdish society (from rural/feudal/religious to urban/modern/secular and nationalist) following the effects of migration trends from rural to urban areas and expansive urbanization, the role of these actors in society is also in decline.

- There is an urgent need for 'new' youth engagement mechanisms especially in addressing the personal development of young people. These instruments; however, should incorporate the sensitivities of youth and cultural characteristics of Turkey's southeast. These instruments should reduce the tensions between different youth clusters (in particular between Islamists and Nationalists) in Turkey's southeast. A major role, in this regard, rests on the political elites in absorbing a peacebuilding agenda in their political activities.

Therefore, the following recommendations are made as a result of the assessment of youth issues and challenges in Turkey's southeast:

- The existing security-based conflict prevention mechanisms should be transformed into peacebuilding instruments.

- A holistic attitude that is comprised of structural (economic and educational) and personal (identity) determinants must be a priority for peacebuilders.

- A contextual understanding of youth challenges and issues must be emphasized in youth interventions that specialize on different youth groups, such as rural, urban or migrant youth.

- The community-level actors should be taken into consideration by empowerment efforts at different levels, such as training for peacebuilding, institutionalization and funding opportunities.

- A locally-owned peacebuilding strategy can engage young people to participate in activities, which would change the perceptions of youth as troublemakers.

\section{Conclusion}

Socially integrated individuals participate as full members of society by gaining access to a comprehensive set of rights and opportunities as individual parts of a collective. In conflict societies, the integration of young people into society is recognized as one of the most essential components of war-to-peace transitions (Sommers, 2006a; 2006b). 
Indeed, occurrences of political and anti-social violence often instigated by young people in post-conflict settings urges the need to address young people's challenges in the well-functioning social systems. Indicators of exclusion (economic, educational or political), in this context, offer an explanatory framework. In conflict societies, exclusion differs significantly compared to normal societies, where other conflict drivers (ethnic, ideological or religious social markers) are often negligible factors. The process of peacebuilding in fragile contexts thus requires a wider perspective, taking into consideration the contextual conflict drivers and root causes in a specific conflict. It is particularly significant in complex conflict situations such as in Turkey's southeast. The dynamics of exclusion, as an outcome of the conflict, is a relatively understudied area. However, as exclusion is also a phenomenon prevalent in normal societies, especially in migrant-abundant locations, it is often a convenient way of programming peacebuilding interventions and of detecting means of addressing such challenges. In these contexts, the fieldwork findings in this research demonstrate that addressing socioeconomic factors and a liberal peacebuilding perspective dominate the overall aim of present conflict prevention and peacebuilding work in Turkey. Therefore, there are a reliance on vocational training, educational support, and recreational activities and basic skills training activities as a means of preventing participation in violence.

However, separating some of the conflict dynamics from peacebuilding interventions may not yield the anticipated post-program results. By explaining these challenges as barriers to peacebuilding, the results of the fieldwork exhibit that the divisions in Kurdish society causes alternative means for youth socialization in venues. Social and political actors often weaken the overall rationale of integrating youth into society and preventing participation in violence.

As civil actors are highly ideologically motivated a crucial role rests on state-led institutions. Complex conflicts require institutions, which are responsive to the challenges that young people face. It can be argued that following the developments, which occurred as a result of the recent peace initiatives, structural violence is a priority for the incumbent government, which is evident in legal improvements (UPOS, 2014). Existing peacebuilding interventions addressing the structural issues could similarly serve as the basis of post-violence period interventions. In contrast to some of the findings in the peacebuilding interventions in different conflicts, however, young people are often familiarized with pro-violence thinking during the higher education years. Therefore, the fieldwork findings discussed in this article can be a key for the success of peacebuilding interventions in Turkey's southeast. In other words, the primary focus should be on the role of the identity formation process, influenced by social and political actors at the personal level. 


\section{References}

1. Alçı, N. (2014), Fırtına gençliği' kontrol edemiyoruz. Milliyet. Retrieved from http:// www.milliyet.com.tr/-firtina-gencligi-kontrol/gundem/ydetay/1953311/default.htm.

2. Boyden, J., \& DeBerry, J. (Eds.), (2004). Children and Youth on the Frontlines. New York: Berghahn.

3. Bozarslan, H., (2008). Kurds and Turkish State. In R. Kasaba (Ed.), The Cambridge History of Modern Turkey: Volume IV: Turkey in the Modern World (pp. 333-356.). Cambridge: Cambridge University Press.

4. Collins, J., (2004). Occupied By Memory: The Intifada Generation and the Palestinian State of Emergency. New York: NYU Press.

5. Darby, J. (2001). The Effects of Violence on Peace Processes. Washington DC: United States Institute of Peace Press.

6. Daiute, C., Beykont, Z., Higson-Smith, C., \& Nucci, L. (2006). International Perspectives on Youth Conflict and Development. New York: Oxford University Press.

7. Del-Felice, C., \& Wisler, A., (2007). The Unexplored Power and Potential of Youth as Peace-builders. Journal of Peace Conflict and Development, 11, 1-29.

8. Fuller, G. A., \& Pitts, F. R., (1990). Youth Cohorts and Political Unrest in South Korea. Political Geography Quarterly, 9, 9-22.

9. Goldstone, J., (1991). Revolution and Rebellion in the Early Modern World. Berkeley: University of California Press.

10. Göksel, A., (2007). Studies on Youth Policies in the Mediterranean Partner Countries: Turkey. Mary le Roi: Euromed Youth III Programme.

11. Hart, J., (2006). The Politics of "Child Soldiers". Brown Journal of World Affairs, 13(1), 217-226.

12. Huntington, S. P. (1996). The Clash of Civilizations and the Remaking of World Order. New Delhi: Penguin Books.

13. Heinsohn, G. (2003). Sohne und Weltmacht: Terror im Aufsteig und Fall der Natione. Zurich: Orell Fussli.

14. Hendrixson, A. (2003). The Youth-bulge: Defining the Next Generation of Young Men as a Threat to the Future. Political Environments, 10, 27-30.

15. Hilker, L., \& Fraser, E. (2009). Youth Exclusion, Violence, Conflict and Fragile States. Report prepared for DFID's Equity and Rights. London: Social Development Direct.

16. ICG (International Crisis Group). (2016). Turkey's PKK Conflict: The Death Toll, A Commentary By Berkay Mandiraci. Brussels: ICG.

17. Kaplan, R. D. (1996). The Ends of the Earth: From Togo to Turkmenistan, from Iran to Cambodia - A Journey to the Frontiers of Anarchy. Massachusetts: Peter Smith Publications Inc.

18. Kemper, Y. (2005). Youth in War-to-Peace Transitions. Approaches of International Organizations, Berghof Report 10. Berlin: Berghof Research Center for Constructive Conflict Management.

19. Kurtenbach, S. (2008). Youth in Conflict and Peace-building - Between Protection and Neglect. Paper presented at the ISA conference, 26-29th March, San Francisco. 
20. Machel, G. (1996). Promotion and Protection of the Rights of Children: Impact of Armed Conflict on Children. New York: UN.

21. Machel, G. (2001). The Impact of War on Children: A Review of Progress since the 1996 Report on the Impact of Armed Conflict on Children. London: Hurst and Company.

22. McEvoy-Levy, S. (2001). Youth as Social and Political Agents: Issues in Post-Settlement Peace Building. Kroc Institute Occasional Paper 21. Notre Dame: Kroc Institute for International Peace Studies.

23. McEvoy-Levy, S. (2006). Troublemakers or Peacemakers? Youth and Post-Accord Peace Building. Notre Dame: University of Notre Dame Press.

24. McEvoy-Levy, S. (2011a). Children, Youth, and Peacebuilding. In S. Byrne, T. Maytok and J. Senehi (Eds.), Critical Issues in Peace and Conflict Studies: Theory, Practice, and Pedagogy (pp. 159-176). New York: Lexington Books/Rowman \& Littlefield.

25. McEvoy-Levy, S. (2011b). Playing 'Catch with a Hatchet': Integrating Children's Knowledge into Post-War Peacebuilding. In D. T. Cook and J. Wall (Eds.), Children and Armed Conflict: Cross-Disciplinary Investigations (pp. 151-170). Houndmills: Palgrave.

26. McEvoy-Levy, S. (2013). Youth and Peacebuilding. In R. MacGinty (Ed.), .Routledge Handbook of Peacebuilding (pp. 296-308). New York: Routledge.

27. Neyzi, L. (2001). Object or Subject? The Paradox of 'Youth' in Turkey. International Journal of Middle East Studies, 33, 411-432.

28. Özerdem, A., \& Podder S., (2015). Youth in Conflict and Peacebuilding. London: Routledge.

29. Özoğlu, H. (2004). Kurdish Notables and the Ottoman State. Albany: State University of New York Press.

30. Pruitt, L. (2008). They Drop Beats, Not Bombs. Music and Dance in Youth Peacebuilding. Australian Journal of Peace Studies, 3, 14-32.

31. Richards, P. (1996). Fighting for the Rainforest: War, Youth and Resources in Sierra Leone. Oxford: James Currey.

32. Schwartz, S. (2010). Youth and Post-Conflict Reconstruction: Agents of Change. Washington: United States Institute of Peace Press.

33. Shepler, S. (2005). The Rites of the Child. Global Discourses of Youth and Reintegrating Child Soldiers in Sierra Leone. Journal of Human Rights, 4, 197-211.

34. SODES (Sosyal Destek Programı) (2013). Değerlendirme Toplantısı Özet Sonuç Raporu. Ankara: SODES.

35. Sommers, M. (2006a). Youth and Conflict: A Brief Review of Available Literature, Washington DC: USAID.

36. Sommers, M. (2006b). Fearing Africa's Young Men: The Case of Rwanda, Social Development Papers Conflict Prevention and Reconstruction, Paper No. 32. Washington: The World Bank.

37. Steinberger, M. (2001, October 21). Interview with Samuel P. Huntington. The Guardian. Retrieved from http//www.guardian.co.uk/world/2001/oct/21/Afghanistan.religion2. 
38. Tezcür, G. M. (2015). Violence and Nationalist Mobilization: The Onset of the Kurdish Insurgency in Turkey. Nationalities Papers, 43(2), 248-266.

39. Urdal, H. (2004). The Devil in the Demographics: The Effect of Youth Bulges on Domestic Armed Conflict 1950-2000. Washington: World Bank Working Papers Series.

40. UN (United Nations). (2004). World Youth Report 2004. New York: United Nations Department of Economic and Social Affairs.

41. UNDP (United Nations Development Program). (2008). Insani Gelisme Raporu: Türkiye'de Gençlik. Ankara: Birleşmiş Milletler Kalkınma Programı Türkiye Temsilciliği.

42. UNSC (United Nations Security Council). (2001). Prevention of Armed Conflict Report of the Secretary-General. New York: UN.

43. UPOS (Undersecretariat of Public Order and Security). (2014). The Silent Revolution: Turkey's Democratic Change and Transformation Inventory. Ankara: UPOS.

44. World Bank. (2011). World Development Report: Conflict, Security and Development, Washington: World Bank.

45. Yavuz, M. H. (2001). Five Stages of the Construction of Kurdish Nationalism in Turkey. Nationalism \& Ethnic Politics, 7(3), 1-24. 